\title{
Spatial linkages of local market in Nepal: A case study of Panchkhal Kavrepalanchowk, Nepal
}

\author{
Kedar Dahal \\ Department of Geography, Tri-Chandra Multiple Campus, Kathmandu, Nepal. \\ Received 5 August, 2018; Accepted 13 September, 2018
}

\begin{abstract}
Market centers are the points of interactions for socio-economic functions and services. The relative importance of the market centers are largely dependent on the functional range and magnitude which includes both commercial and non-commercial functions offered by market centers. This study tries to analyze the spatial linkages of Panchkhal market, through the collection of primary data and information in December, 2016. Generally, five types of functions are identified in the market and most of them are retail shops of mixed types. Catering and occupational services have also increased in the market in the recent years. Panchkhal Market mostly depends on Banepa and Kathmandu for goods and services. Medical facilities are supplied mainly from Dhulikhel and Banepa, and occasionally from Kathmandu. Birgunj, Hetauda, Bhaktapur are main supplier points of cement, rod and chemical fertilizer. It is relatively a small market center and provides small range of goods and services to the local communities. After declaration of the municipality in 2014, its zone of influence is expanding mostly towards adjoining rural villages of north and south. Nevertheless, fluctuation of customers' visit was also observed during the filed study.
\end{abstract}

Key words: Market center, functional linkages, functional range and magnitude, costumer, goods and services, local communities.

\section{INTRODUCTION}

Conceptually, the term linkage denotes the functional relationships between market center and rural hinterland to provide various types of services and delivery opportunities to beneficiaries (Pradhan, 2004). Christaller (1933) had a study of central places and their interactions. According to him, central places are distributed over a uniform plane of constant population density and purchasing power in all directions, thus reducing the transportation cost and price. Once a threshold gets established, the central place tries to expand until the range reach a circular pattern in a way that settlements function as the central places providing services to surrounding areas, expanding its urban system. Symanski and Webber (1974) have developed functional approach to the market and visualized complex behavior of traders and customer's mobility (Rizal, 1980-1981).

E-mail: kedar.geog@gmail.com.

Author(s) agree that this article remain permanently open access under the terms of the Creative Commons Attribution License 4.0 International License 
Many geographers in Nepal were also involved in the study of market centers and their hierarchy, range of goods and spatio-temporal relationships. Shrestha (1981), Rizal (1980-1981), Khatiwada (1988), Kareriya (1991), Mandal (1995), KC and Pradhan (1980-1981) are some of those who studied rural market centers in Nepal.

Transaction has a significant relationship with geographical distance, infrastructure and growing trend of civilization. In many developing agrarian countries, most of the market centers are either small or periodic in nature; and these markets may exist side by side in several cases (Shrestha and Rizal, 1979). Small local markets gradually turn into big permanent markets as population density, urbanization and accessibility increase. With the view of economic and commercial motive, two systems of market are established in Nepal, permanent and periodic or Haats (Bazar). Permanent markets are spatial nodes characteristically associated with functional units of varying magnitude, proportional with the population size and range of household; which are likely to increase or sometimes decrease based on changes in the affordability of population and trend of urbanization (Shrestha and Rizal, 1979). Sometimes, such changes in the number of functional units are determined by alteration in the need of people caused by natural calamities like earthquakes, drought, etc.

Several studies were conducted in the past on the nature of rural markets in Nepal. These studies were made and focused on locational pattern, functional range, magnitude of periodic markets etc. Shrestha (1981) analyzed the effect of price level in shaping the service area of market center in Araniko highway areas including Panchkhal. Considering price-index value, he concluded that difference in price have an effect on the extent and form of the market centers. Shrestha (1981) also studied the structure of rural market center in terms of relative importance, spatial pattern, functional roles and interaction patterns in the Kathmandu valley. Pradhan and Routray (1992) concluded that those markets located on highway-side can be regarded as those integrated into rural- urban system, extending on road- locations and places of access to rural services. Furthermore some market centers far from main roads were poorly integrated, thus road and rural production play an important role in the development of market centers and agriculture.

However, very few permanent rural markets have been studied in the hill area of Nepal in terms of their spatial linkages, their hinterland and magnitude and range of services. These rural markets provide goods and services to the local community and to boost the local economy as well. As the study area is located in the midhill of Nepal, the outputs of this study depict the market size, its linkages and expansion. The objective of the present paper is to identify the spatial linkages of Panchkhal. Attempts are also made to examine the magnitude and range of goods and services, which will be very useful for the local planner and development practitioners in the formulation of policy and programmes for socio-economic and urban development.

\section{MATERIALS AND METHODS}

The primary data was collected through the market survey with clearly defined semi-structured questionnaire. Data and information was collected from the customers, shopkeepers and local business organizations, using purposive sampling techniques. Out of the total business units (318), only $20 \%$ were selected randomly for direct interview from the group of factories, and industries and institutions and services such as retailers, caterers and professionals. Since the market is homogeneous in nature, it is expected that this size is enough to address the current market status and their linkages. Similarly, altogether 72 customers were interviewed and opinion survey was conducted in a single day including morning, day and evening time. A separate list of checklist was also used to collect market activities and types of business units through the direct observation.

In addition, interviews were made with the key informants such as traders, government officials, and distant customers. Some informal conversation was also made with the local women, elderly and farmers in the points of neighborhoods and local veterans. Classification of the data rested on the tabulation of attributes, while presentation was based on relevant graphical diagrams. The secondary data collection was made through various sources like Panchkhal Municipality Office, Central Bureau of Statistics, District Development Committee, Kavrepalanchowk; and other unpublished reports related to the market center study in Nepal and elsewhere.

\section{The study area}

Panchkhal is a rapidly growing rural market developed at the edge of Araniko highway in mid-hill region of Nepal. It can be looked upon as a relatively small market center, the forthcoming perspective mentioned in this research article depicts its slowly expansive tendency. Panchkhal was declared municipality in 2014; incorporating seven Village Development Committee (VDC) namely Panchkhal, Hokse, Sathighar, Baluwa, Kosidekha, Kharelthok and Anaikot of the surrounding area. It is a linear town in the center of the valley. The town is a junction of the Araniko Highway and Tamaghat-Thuloparsel partially black topped road.

Extending between $85^{\circ} 38^{\prime} \mathrm{E}$ and $27^{\circ} 41^{\prime} \mathrm{N}$, Panchkhal valley is about $45 \mathrm{~km}$ far from capital city Kathmandu, and well connected by roads and transportation. It is a valley surrounded by a series of mountains with passes. Most of the valley is occupied by mountains, with upper Mahabharata ranges and snow-capped mountain on the north during winter. A series of mountain/hills separates the valley from Dhulikhel on the west and Dolalghat on the east (Figure 1). The market lies at an elevation of 841 meter from the mean sea level.

Agriculture is the main source of livelihood. Some people are engaged in small scale cottage industries. Livestock rearing adds to domestic income; while trade and remittance are other source of income of the local people. Population in this municipality according to the population census of 2011 was 37,797 , and occupies 103 square kilometer (Centre Bureau of Statistics, 2012; Panchkhal Municipality Office, 2018). Settlements are disperse except linear agglomerate in the market area. It has a police post, an army barrack, five commercial and development banks, four financial institutions (saving and credit), four co-operatives, seven money transfer, one youth club, one post-office, one Nepal telecom office and a dozen of Agro vets. 


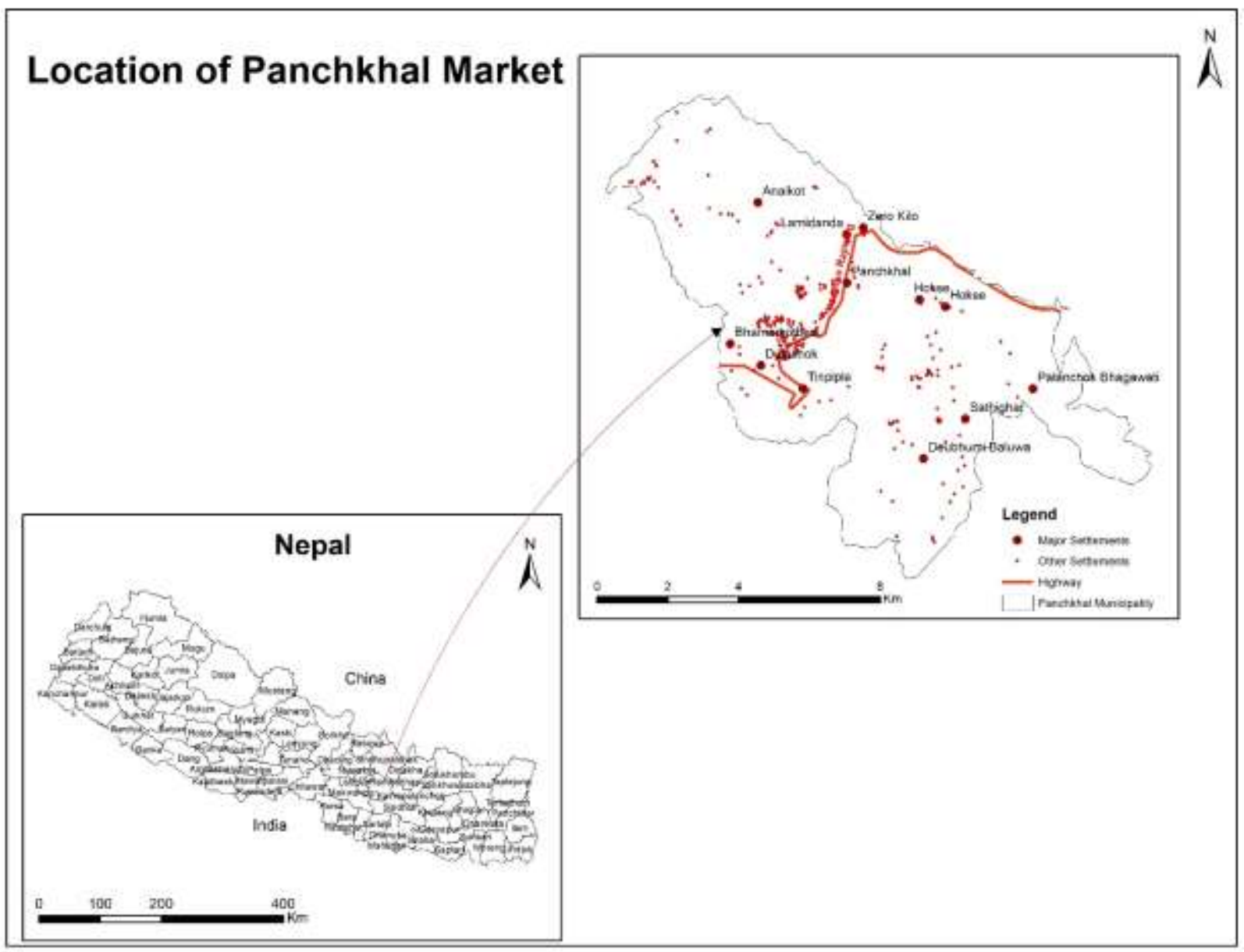

Figure 1. Location of Panchkhal Market (Map by BR Shrestha).

Table 1. Types of functions available in the Panchkhal Market.

\begin{tabular}{lcc}
\hline Types of functions & Numbers & $\%$ \\
\hline Retail Services & 104 & 32.70 \\
Catering Services & 47 & 14.89 \\
Private and Professional Services & 94 & 29.56 \\
Factories and Industries & 14 & 4.40 \\
Institutions & 59 & 18.55 \\
Total & 318 & 100.00 \\
\hline
\end{tabular}

Source: Field Survey, 2016.

\section{RESULTS AND DISCUSSION}

\section{Functional range and magnitude}

Retail shops of mixed type have dominated the market center. Catering services were growing in the market (Table 1). Occupational services are below the retail shops in the rank of numbers, comprising mostly of tailoring and repairing garages. Housing related shops and services are also growing. These include electrical goods and services and cement blocks for housing and cement rings for water wells. Community forest, which supplies sufficient timber for furniture and housing, is also growing; consequently, furniture firms are also growing. Looking on the number of organizations or institutions, one could find the agro-suppliers considerably more indicative of the dependence of economy of people about the Panchkhal market center on farming and livestock; while, educational institutes and money transfers are following it in rank.

The direction of the growth of the market was primarily controlled by the highway or at the break of bulk point (KC and Pradhan, 1980/81; Shrestha and Rizal, 1979). Permanent markets like Panchkhal, which is developed in the Araniko Highway area do not have its origin as a temporary Haat, and started as the permanent market center. The main reason is that Panchkhal was almost an expansion of service area of other old permanent market centers like Bhaktapur, Banepa, Panauti, Sankhu and Dhulikhel from the very beginning. The business 
Table 2. Types and magnitude of retails services in the study area

\begin{tabular}{llcc}
\hline S/N & Retailer services & Total number & $\%$ \\
\hline 1 & Grocery and cloths mixed/ration & 36 & 34.7 \\
2 & Fruits and vegetable- seller & 4 & 3.8 \\
3 & Meat and fish & 4 & 3.8 \\
4. & Draper/ clothing items & 11 & 10.6 \\
5 & Ornament and readymade clothes & 15 & 14.4 \\
6 & Kitchener & 7 & 6.7 \\
7 & Hardware / sanitary wares & 10 & 9.7 \\
8 & Stationary & 11 & 10.6 \\
9 & Footwear & 4 & 3.8 \\
10 & Paint house & 2 & 1.9 \\
Total & & 104 & 100.0 \\
\hline
\end{tabular}

Source: Field Survey, 2016.

Table 3. Types of catering services in the study area.

\begin{tabular}{llcc}
\hline S/N & Catering service & Total number & $\%$ \\
\hline 1 & Tea, breakfast, confectionary & 21 & 44.7 \\
2 & Cold drinks and beverage & 10 & 21.3 \\
3 & Hotels/ motels & 14 & 29.8 \\
4 & Hotel, lodge & 2 & 4.2 \\
\hline
\end{tabular}

Source: Field Survey, 2016.

community of these old permanent markets have contributed significantly to the growth and development of Panchkhal market and other market centers along the major highways, traditional trail routes and break of bulk points or trading nodes; which have socio-economic linkages with their original places (Shrestha and Rizal, 1979). It is also linked with small and periodic market centers lying under its sphere of influence such as Melanchi, Sipaghat, Dolalghat and other market centers of eastern hill districts.

\section{Spatial pattern of linkages}

With the help the of primary information available from the traders and organizational officials, the hinterland of customers to the Panchkhal market area is wide because of the Araniko highway and motor tracks connecting it to the neighboring municipalities and rural municipalities. Motels, lodges, petrol pump and auto parts fairly receive visits from the itinerants. Sindhupalchok, Barhabise, Melamchi, Sipaghat, and Dolalghat are the main neighboring central places receiving facilities from Panchkhal market.

Colleges have been welcoming students from as far as Bhaktapur on the west, Tinpiple and also from distant locations. People from Khawa travelled towards Dhulikhel municipality as their nearest market center and higher academics. At the time of the field visit, most customers came from Panchkhal municipality itself. Undoubtedly, the farthest-range travelling customers involved the purchases of goods/services like computer hardware, kitchenware, auto parts, furniture, medical treatment, agro-vet items, ring and blocks, and finances from the town. The main types of functional transactions in Panchkhal are retail shops, catering, factories, organizations and personal occupations (Tables 2 to 6 ).

The market has inseparable relationship with another rural, rural-urban, or urban market for the continuity of its functions. Panchkhal market is basically dependent on Banepa and Kathmandu for supplies with nearly $70 \%$ of its required commodities. Medical facilities are being supplied chiefly from Dhulikhel and Banepa and occasionally from Kathmandu. Birgunj, Hetaunda, Amlekhgunj, and Bhaktapur are major suppliers of cement, rod and chemical fertilizer. Auto parts, tractor and tiller tools, hand tool, power tool and machines are gotten form Bhaktapur, Kathmandu, Birgunj, and India. Cotton for cotton bed industry is imported from Banepa and Birgunj (Table 7).

Other products like motorbikes and fruits maintained the transaction from Kathmandu; while meat, timber, milk etc. from nearby Village Development Committee (VDC). Magnetite was transported from Jiri and Tatopani. 
Table 4. Types of private and professional services in the study area.

\begin{tabular}{clcc}
\hline S/N & Occupation service & Total number & $\%$ \\
\hline 1 & Hair-cutter saloon & 7 & 7.4 \\
2 & photo studio cum curio & 2 & 2.1 \\
3 & Pharmacy/ clinic & 2 & 2.1 \\
4 & Photocopy-fax-internet & 2 & 2.1 \\
5 & Tailoring & 14 & 14.7 \\
6 & Radio, watch repairing & 2 & 2.1 \\
7 & Computer institute & 4 & 4.2 \\
8 & Auto-mobile part \& tool & 4 & 4.2 \\
9 & Jeweler's shop & 4 & 4.2 \\
10 & Petrol pump & 2 & 2.1 \\
11 & LPG gas dealer & 3 & 3.1 \\
12 & Well ring and block & 6 & 6.3 \\
13 & Cotton-bed manufacturing & 1 & 1.1 \\
14 & Diary chilling plant & 3 & 3.1 \\
15 & Saw mill & 1 & 1.1 \\
16 & Grill and frame industry/workshop & 2 & 2.1 \\
17 & Motorcycle showroom & 1 & 1.1 \\
18 & Parlor and training & 5 & 5.3 \\
19 & Tractor/ tiller parts & 3 & 3.1 \\
20 & TV repairing & 1 & 1.1 \\
21 & Automobile garage/parts & 5 & 5.3 \\
22 & Motorcycle garage/parts & 13 & 13.7 \\
23 & Mobile phone repairing and electronics & 8 & 8.5 \\
Total & & 95 & 100.0 \\
\hline
\end{tabular}

Source: Field Survey, 2016.

Table 5. Types of factories recorded in the study area.

\begin{tabular}{llc}
\hline $\mathbf{S} / \mathbf{N}$ & Factory and industries & Total number \\
\hline 1 & Rice mill & 2 \\
2 & Rice + oil mill ( mixed) & 1 \\
3 & Furniture industries & 8 \\
4 & Earthen pottery & 2 \\
5 & Magnetite industry or mill & 1 \\
Total & & 14 \\
\hline
\end{tabular}

Source: Field Survey, 2016.

The information collected from the customers provided supporting facts to the findings of the hinterland of Panchkhal Market as well as other higher-order and lower-order markets away from it, where customers were receiving their required commodities. Among the customers, $60 \%$ were purchasing commodities (mainly grocery, vegetable and fruits etc.) from Panchkhal, $13.3 \%$ from Banepa, 10\% from Anaikot, 6.6\% from Kathmandu, and the remaining from nearest local markets. Similarly, $70 \%$ of commodities related to the electrical and electronics, watch, ornaments, clothes etc. were purchased from Banepa and 5\% from Kathmandu. Few people of Panchkhal area went to Banepa for banking services, and Dhulikhel for administration purpose.

Again, while examining the next destination markets for other extra commodities and services, Panchkhal market provided almost total facility of tailoring and haircut to its customers. For repairing work, almost no customers seemed to have next choice of destination other than Panchkhal market. Above all, $100 \%$ facility of financing and banking was retained from Panchkhal. However, schooling and higher-study privilege from Panchkhal do 
Table 6. Types and number of institutions in the study area.

\begin{tabular}{llc}
\hline S/N & Organization & Number \\
\hline 1 & Nepal bank Itd & 1 \\
2 & Money transfer & 7 \\
3 & Commercial/development bank & 4 \\
4 & Finances & 4 \\
5 & Co-operatives & 4 \\
6 & Agro- supplier & 12 \\
7 & Veterinary supplier & 2 \\
8 & Club & 1 \\
9 & Brick depot & 1 \\
10 & Police barrack & 1 \\
10 & Polyclinic & 2 \\
12 & Forlorn care center & 1 \\
13 & Private school / govt. school & 6 \\
14 & Higher secondary school & 3 \\
15 & Post office & 1 \\
16 & Nepal telecom office & 1 \\
17 & Temples & 3 \\
18 & Cine hall & 1 \\
19 & Chemical fertilizer & 1 \\
20 & Metal scrap collection & 1 \\
21 & Campus & 2 \\
Total & & 59 \\
\hline
\end{tabular}

Source: Field Survey, 2016.

Table 7. Supplying Commodities to Panchkhal market.

\begin{tabular}{clcl}
\hline S/N & Supplying Points (Markets) & $\%$ & Types of commodities \\
\hline 1 & Banepa & 35.0 & Timber, cotton, motorcycle, plastics ware and many more \\
2 & Kathmandu & 33.9 & Auto parts, motorcycle, cement, gold, fruit, hardwires, TV, mobile, Medicines. \\
3 & Panchkhal & 17.4 & Retail item, feed for poultry. \\
4 & Dhulikhel & 1.9 & Medical treatments, cement, hardwires, hotel. \\
5 & Bhaktpur & 2.5 & Auto parts, earthen pots. \\
6 & Anaikot & 1.8 & Timber, vegetable, milk. \\
7 & Lamidanda & 0.3 & Timber \\
8 & Amlekhgunj & 0.4 & Petroleum \\
9 & Thankot & 1.1 & Petroleum \\
10 & Sipaghat & 1.2 & Ring blocks ingredients \\
11 & Tinpaple & 0.9 & Timber, milk, vegetables \\
12 & Kunta & 0.4 & Timber \\
13 & China & 0.8 & Agro items \\
14 & India & 0.9 & Garage tools, agro item \\
15 & Birgunj & 0.8 & Cotton, cement, chemical fertilizer etc. \\
16 & Others & 0.7 & Mixed grocery/garments etc \\
\hline
\end{tabular}

Source: Field Survey, 2016.

not exceed 45\%; Banepa, Kathmandu and their own Locality being the places of selection.
Nevertheless, $90 \%$ of jewelry purchases were made from Banepa and the rest from Panchkhal, which is 
Table 8. Frequency of Customers Visiting the Market.

\begin{tabular}{clcccc}
\hline \multirow{2}{*}{ S/N } & \multirow{2}{*}{ Location } & \multicolumn{2}{c}{ Visits Daily (Grocery, vegetables etc.) } & \multicolumn{2}{c}{ Visits other than grocery, vegetables etc. } \\
\cline { 3 - 6 } & & Frequency & $\%$ & Frequency & $\%$ \\
\hline 1 & Panchkhal & 18 & 59.9 & 7 & 23.3 \\
2 & Banepa & 4 & 13.3 & 21 & 70.0 \\
3 & Kathmandu & 2 & 6.6 & 2 & 6.7 \\
4 & Jirokilo & 1 & 3.3 & - & - \\
5 & Anaikot & 3 & 10.0 & - & - \\
6 & Baluwa & 1 & 3.3 & - & - \\
7 & Aaathkilo & 1 & 3.3 & - & - \\
8 & Kanskote & 1 & 3.3 & - & - \\
9 & Puranobazar & 1 & 3.3 & & - \\
\multicolumn{1}{l}{ Total } & $=30$ & $=100 \%$ & & & - \\
\hline
\end{tabular}

Source: Field Survey, 2016.

Table 9. Kinds of commodities and Services; and Number of Customers involving Panchkhal and other Market centers.

\begin{tabular}{|c|c|c|c|c|c|c|c|c|c|c|}
\hline $\mathrm{S} / \mathrm{N}$ & Locations & Tailoring & Barber & Jewelry & Repairing & Medical treatment & Schooling & Campus & Banking & Total \\
\hline 1 & Paanchkhal & 21 & 20 & 1 & 25 & 5 & 12 & 6 & 30 & $120^{*}$ \\
\hline 2 & Banepa & 2 & - & 29 & -- & 7 & 2 & 5 & & 45 \\
\hline 3 & Kathmandu & & & 1 & 1 & 1 & 2 & 3 & & 8 \\
\hline 4 & Dhulikhel & & & & & 14 & & & & 14 \\
\hline 5 & Rampur & 1 & 1 & & & & & & & 2 \\
\hline 6 & Jirokilo & 1 & 3 & & 1 & & 3 & 1 & & 9 \\
\hline 7 & Anaikot & 2 & 2 & & & & 2 & & & 6 \\
\hline 8 & Jyamdi & & & & & & 1 & & & 1 \\
\hline 9 & Baluwa,sera & & & & & & 2 & 1 & & 3 \\
\hline 10 & Jaisithok & & & & & & 1 & & & 1 \\
\hline 11 & Majhidi & & & & & & 1 & & & 1 \\
\hline 12 & Purnobazaar & 1 & 1 & & & & & & & 2 \\
\hline 13 & Kanskote & 1 & & & & 1 & & & & 2 \\
\hline 14 & Dhakalthok & 1 & 1 & & & & 1 & & & 3 \\
\hline Total & & 30 & 28 & 31 & 27 & 28 & 27 & 16 & 30 & 217 \\
\hline
\end{tabular}

Source: Field Survey, 2016.

comparatively lower. Regarding the hospital facility, majority of them reached Dhulikhel and Banepa for severe cases. Tables 8 and 9 further shows the functional interactions among the market centers including Panchkhal.

\section{Frequency of customers' Visit to Panchkhal market}

One of the important aspect of the market is the customer visit to the market, which is defined in terms of the frequency of market visit. Many customers visit Panchkhal market daily for goods; a very few are visit occasionally (Table 10). It is found that customers usually travel to local markets for their daily needs and engage in distance travel for garments, furniture, ornaments, machinery items and vehicles.

Fluctuation of customers' visit was also observed during the field study. Units of transaction like cement ring for water wells and cement blocks for houses, photocopy and fax, hardwires, co-operatives, motorcycle show-room, stationary, vegetable shop, collage, iron grill workshop, auto parts, computer institute, electronic, drapers, tractors parts, poultry are experiencing increasing number of customers (Table 11).

Kitchenware, lodge, grocery, victual stores, mobile house, petrol pump, fruit shop, metal shop, tailoring, magnetite factory, tea shop, cold drinks, and barbers are almost constant in the rate of visiting customers. Somehow, the rate of frequency of customer visit 
Table 10. Frequency of Customer Visits.

\begin{tabular}{lccl}
\hline Temporal Parameters & Number of customers & $\%$ & Type of trade/transition unit \\
\hline Daily & 1692 & 98.8 & Groceries, ration store, dairy, cosmetics, drapery, vegetables, electrics \\
Once in a week & 4 & 0.20 & Furniture, girl, poultry \\
Twice in a week & 3 & 0.18 & Readymade clothes, agro, saw-mill \\
Once in a month & 6 & 0.35 & Metal scraps collector \\
Twice in a month & 4 & 0.20 & Motorcycle showroom \\
As per need & 3 & 0.18 & Magnetite factory, ring blocks, finance etc. \\
\hline
\end{tabular}

Source: Field Survey, 2016.

Table 11. Customer Perceptions for Marketing Goods and Services in Panchkhal.

\begin{tabular}{lc}
\hline Descriptions & $\%$ \\
\hline Increasing rate of customers & 50.0 \\
Almost constant & 18.9 \\
Decreasing rate of customers & 31.1 \\
\hline
\end{tabular}

Source: Field Survey, 2016.

Table 12. Reasons for increasing customers in Panchkhal market.

\begin{tabular}{llc}
\hline S/N & Reasons for increasing customers & $\%$ \\
\hline 1 & Quality commodities & 19.2 \\
2 & Transport facilities & 19.2 \\
3 & Managed market & 11.5 \\
4 & Municipal expansion & 7.7 \\
5 & Standard of livelihood & 7.7 \\
6 & Population increase & 4.3 \\
7 & Local Prestige & 7.7 \\
8 & Increasing fashion & 7.7 \\
9 & Cheaper goods & 15.8 \\
\hline
\end{tabular}

Source: Field Survey, 2016.

decreased in cosmetics, earthen pots, agro, shoe-maker, hotel (beverages), sawmill, readymade, tools, ply, jewelry, furniture etc.

\section{Fluctuation in the demands of goods}

The credible opinions regarding the increase of customers were found. The opinion suggests that customers are increasing because of increasing transport facility and roads, quality of commodities, supply of different standards of commodities with different price ranges, geographic expansion of municipality and uplifted standard of livelihood of people (Table 12). On the contrary, the decrease of customers in other units are reported as the use of pesticides and lower agriculture production, unemployment, and substitution of original goods such as wooden furniture and metals by plastics and glassware, etc. (Table 13).

\section{Potentials for development of Panchkhal market}

Farming and dairy products are the main natural sources of income and utility to the Panchkhal market. Araniko highway and high population and settlements in the surrounding areas makes this area a trade junction. Moreover, furniture industries, garages, educational institutes and a number of financial organizations, meat, egg, mushroom, ply industries, magnesite industries are ever growing, which will increased the potential for further expansion in the future. A number of cold- stores (two at present) are growing. Perspectives on forest management, horticulture, logistics, and tools are ever expanding (Table 14).

\section{Hindrances to prosperity of the market}

Infrastructural progress and commodity threshold in the Panchkhal market has come up with sufficient initiatives towards its municipal prospects. Despite the fact that agricultural products and animal rearing are the major occupation and has potentially high sources of income, only a meager area of arable land has irrigation facility so far. Supply of potable water to every home has been hardly met. Generally, the inorganic mode of farming was reckoning negative impact on soil, ecosystem and hygiene. Waste management and maintenance of sewage is still poor.

The additional hindrances to the development of the sector are load shedding and power cut has discouraged the investors to open up new factories. Unemployment, lack of practical skills, lack of planning and projects were manifested as other reasons (Table 15).

\section{Conclusion}

Drawing a synoptic sketch from the above details of the 
Table 13. Reasons for decreasing customers in Panchkhal market.

\begin{tabular}{llc}
\hline S/N & Reasons for Decreasing Customers & $\%$ \\
\hline 1 & Number of trade units increasing & 17.6 \\
2 & Only seasonal demands & 11.7 \\
3 & Unemployment & 11.7 \\
4 & Less agricultural production & 5.8 \\
5 & Domestic reuse of goods & 5.8 \\
6 & Replacement by alternative devices & 5.8 \\
7 & Periodic close-down of crusher & 5.8 \\
8 & Free domestic internet & 11.8 \\
9 & Pesticide use & 5.8 \\
10 & Chinese items of varying quality and price & 5.8 \\
11 & Geophysical calamities & 5.8 \\
12 & Replacement of wooden furniture by aluminum, glass wares and plastics & 5.8 \\
\hline
\end{tabular}

Source: Field Survey, 2016.

Table 14. Customer's opinions on potential development of Panchkhal market.

\begin{tabular}{lcc}
\hline Parameters & Frequency of opinions & $\%$ \\
\hline Banking and financial organizations & 5 & 6.9 \\
Easy Access, Road and Transportation & 8 & 11.1 \\
Market junction/ Nodal Points & 8 & 11.1 \\
Increasing Industries & 15 & 20.8 \\
Animal, husbandry, poultry farming & 3 & 4.2 \\
Educational / technical center & 3 & 4.2 \\
Developing Dry ports & 7 & 9.7 \\
Education/Colleges & 2 & 2.8 \\
Garages & 3 & 4.2 \\
Irrigation project & 2 & 2.8 \\
Improved Agriculture farming \& seed production & 12 & 16.7 \\
Others & 4 & 5.5 \\
Total & 72 & 100.0 \\
\hline
\end{tabular}

Source: Field Survey, 2016.

Panchkhal market, it is concluded that urban markets are the growth poles of rural areas. The local products of rural areas and generative men-power are centralized towards urban market. It has been shown that there are 321 units of trade-and -transaction existing in the Panchkhal market. The spatial pattern of urbanization in Panchkhal market was centered on the heart of the market and along the road lines. The degree of variation in the price- level of commodities depend on the extent of accessibility or supply and earning of customers. Although, the municipality cannot compete with the bigger towns like Banepa, yet it compares higher with respect to the others like Dolalghat and Sindhupalchowk. The trend of demotion of some transactional units is beneath those which underscored their future promotion. The Tempo-Spatial relation of the market is good with cities like Banepa, Tatopani, Birgunj, Kathmandu and Bhaktapur etc. for the exchange of commodities. The major exports from the market includes furniture, dairy products, fruits and vegetables, as well as poultry and livestock, showing their comparative advantages. Given priority in advance to the system of farming and drainage, sanitation and recycling, expansion of community forests, dairies, trade junction etc., Panchkhal foreshows the possibility to be one of the eminent municipal business sector in the region.

\section{CONFLICT OF INTERESTS}

The author has not declared any conflict of interests. 
Table 15. People's opinions on hindrances to the market development.

\begin{tabular}{llc}
\hline S/N & Hindrances & Frequency \% \\
\hline 1 & Lack of potable water & 16.9 \\
2 & Unmanaged Sewage drain & 12.6 \\
3 & Garbage or solid wastes pollution & 15.4 \\
4 & Pesticides \& Chemicals & 7.0 \\
5 & Lack of skilled manpower & 5.6 \\
6 & Insufficient pitch-top roads \& parking & 8.4 \\
7 & Procrastination of planning \& projects & 8.0 \\
8 & Insufficient irrigation & 8.4 \\
9 & Load shedding problem & 4.2 \\
10 & Lack of sufficient no. of industries & 2.8 \\
11 & No inspection on farming \& seeds & 2.8 \\
12 & Lack of dry port & 1.4 \\
13 & Lack of well-equipped hospital & 1.4 \\
14 & Unemployment & 2.8 \\
15 & Lack of saving trend & 1.4 \\
& Total & 100.0 \\
\hline
\end{tabular}

Source: Field Survey, 2016.

\section{ACKNOWLEDGEMENT}

The author is thankful to Puspa Ojha and Nawaraj Adhikari for the primary data collection and preparation of field notes, and Buddhi Raj Shrestha for map works. The author also wants to thank Mr. Shankar Nepal, under Secretary, Government of Nepal, for his critical suggestions.

\section{REFERENCES}

Centre Bureau of Statistics (CBS) (2012). National Population and Housing Census, National Report. Government of Nepal. Kathmandu. Available at: https://unstats.un.org/unsd/demographicsocial/census/documents/Nepal/Nepal-Census-2011-Vol1.pdf

Christaller W (1933).Central Places in Southern Germany. Germany. Fischer. Germany.

Kareriya BR (1991). The Periodic Marketing System: A Case Study in Rupandehi District. Unpublished MA Thesis, Submitted to Department of Geography, Tribhuvan University.

KC Bal Kumar, Pradhan PK (1980). A study of market centers in Siddhartha and Prithvi highways. Geographical Journal of Nepal 3(4):1-13.

Khatiwada SP (1988). A Study of Periodic Markets in Dhankuta District. Unpublished MA Thesis, Submitted to Department of Geography, Tribhuvan University.

Mandal UK (1995). The System of Periodic Market Centers: A Case of Saptari District Nepal. Unpublished MA Thesis, Submitted to Department of Geography, Tribhuvan University.
Pradhan PK (2004). Rural urban relations: with particular reference to Nepal. Rural Urban Partnership Programme, Ministry of Loca Development/United Nations Development Programme.

Pradhan PK, Routray JK (1992). Market Centers and Rural Development: A Study in Chitwan District, Nepal. Human Settlements Development Division, Asian Institute of Technology.

Rizal UN (1980-81). Spatio-temporal aspect of periodic markets in Sunsari district. Geographical Journal of Nepal 3-4:36-38..

Shrestha CB (1981). Hierarchy of Central Places in Araniko Rajmarga Area. Unpublished Ph.D. Dissertation. Kathmandu, Tribhuvan University.

Shrestha CB, Rizal UN (1979). Spatial pattern of periodic and permanent market center in Nepal. Geographical Journal of Nepal 2:12-15

Symanski R, Webber MJ (1974). Complex periodic market cycles. Annals of the Association of American Geographers 64(2):203-213. 